\title{
Selection for Catalytic Function with Nucleic Acids
}

Existing protocols for in vitro selection of catalytic polynucleotides are largely derived from the judicious assembly of experimental techniques routinely used in molecular biology. Each new protocol requires the use of the specific techniques that will facilitate the isolation of ribozymes or deoxyribozymes with the desired catalytic activity - that is, the protocol must be designed so as to harness this catalytic activity to help propel the selection process itself. This unit outlines several representative protocols for those who wish to repeat successful selection experiments and for those who seek a conceptual basis to aid in the design and implementation of new selective-amplification protocols for nucleic acids.

\section{STRATEGIC PLANNING}

\section{Amplifying RNA and DNA Molecules}

Several methods for amplifying RNA and DNA molecules are commonly used in molecular biology and, with little or no modification, can be made to play a central role in the selective amplification of catalytic nucleic acids. RNA molecules can be synthesized by chemical means (Wincott et al., 1995) or prepared in large quantities by enzymatic synthesis from DNA templates using T7 RNA polymerase (Milligan and Uhlenbeck, 1989). The conversion of RNA to DNA can be achieved using reverse transcriptase, which is a component of RT-PCR protocols for RNA amplification (Rashtchian, 1994). The details of these methods are described elsewhere (see UNITS 9.2 \& 9.3) and therefore are not covered in this unit.

\section{Creating Variants of Existing Ribozymes}

Basic Protocols 1, 2, and 4 detail the in vitro selection of existing ribozymes. Basic Protocols 1 and 2 describe the selection of group I and RNase P RNA-cleaving ribozyme variants, respectively. Basic Protocol 4 describes the propagation of RNA ligase ribozyme variants by continuous evolution. The natural "self-cleaving" ribozymes are quite small (Symons, 1992), and as a result libraries of variant ribozymes can be prepared by in vitro transcription from synthetic DNA templates that carry partially or fully randomized sequence domains (see UNIT 9.3). However, given the sizes of group I, group II, and RNase $\mathrm{P}$ ribozymes, to introduce mutants into larger catalysts it is necessary to use alternative methods. Fortunately, a number of excellent protocols exist for constructing starting pools of large ribozymes that allow the incorporation of the most desirable mutational patterns. The protocol most commonly used involves performing the polymerase chain reaction (PCR) under mutagenic conditions (Cadwell and Joyce, 1992; Vartanian et al., 1996). These and related DNA amplification protocols are typically used to introduce mutations over the entire length of larger ribozymes. Alternatively, mutations can be introduced in a more focused manner through the targeted integration of mutagenized oligonucleotides into ribozyme-encoding templates (Joyce and Inoue, 1989). Different combinations of fixed, mutagenized, and random-sequence domains can be joined using conventional DNA ligation methods. Alternatively, the DNA shuffling methods (Stemmer, 1994; Zhao et al., 1998) developed for the directed evolution of proteins should also be useful for the preparation of RNA populations by recombination of related ribozymes. 


\section{Creating New Ribozymes from Random-Sequence Pools}

One of the more exciting applications of in vitro selection is the isolation of new classes of catalytic RNAs and DNAs. Usually, new catalysts are isolated from random-sequence pools, or from pools that are biased in favor of a preexisting functional domain. Basic Protocol 3 details the methods used to isolate ribozymes with polynucleotide kinase activity. In its original manifestation (Lorsch and Szostak, 1994), this selection began with an RNA pool that, in addition to random-sequence domains, carried a mutagenized domain that binds ATP. This creates a biased pool wherein greater numbers of molecules are expected to bind the substrate for the reaction. This strategy could be used for other selection efforts, although a starting pool made exclusively of random-sequence molecules may be adequate for many selection goals.

BASIC PROTOCOL 1

Selection for Catalytic Function with Nucleic Acids

\section{IN VITRO SELECTION OF GROUP I RIBOZYME VARIANTS}

A prolific method for the directed evolution of the group I ribozyme was outlined by Joyce and Inouye (1989) and has been used both to probe the structure and function of group I ribozymes and to demonstrate various features of the in vitro selection process. This method exploits the fact that certain constructs of the group I ribozyme catalyze the reversal of the second step of RNA splicing, thereby generating a 3'-tagged ribozyme (Fig. 9.4.1). These self-modifying RNAs are selectively amplified using self-sustained sequence replication (3SR; Guatelli et al., 1990; Fahy et al., 1991) and the resulting RNAs are used to initiate the next round of selection. Although the wild-type ribozyme cleaves DNA substrates poorly (Robertson and Joyce, 1990; Herschlag and Cech, 1990), the isolation of ribozyme variants with improved DNA cleavage activity was one of the earliest achievements for catalytic RNA selections. The details of this in vitro selection protocol are given below.

The following protocol has been adapted from that reported by Beaudry and Joyce (1992). For different desired outcomes, the ribozyme pool may be uniquely mutagenized and subjected to a variation of the protocol described here. It is important to note that the nucleotide sequence of the substrate RNA or DNA used with the ribozyme reaction must be made complementary to the internal guide sequence (IGS) of the ribozyme (Cech, 1990).

NOTE: Buffer solutions, reagents, and oligonucleotides used in all protocols described in this unit should be stored frozen at $-20^{\circ} \mathrm{C}$ and thawed only when needed. Protein enzymes should be stored according to the vendor's instructions.

\section{Materials}

$2 \times$ selection buffer: $60 \mathrm{mM}$ EPPS [4-(2-hydroxethyl)-1-piperazinepropanesulfonic acid; $\mathrm{pH} 7.5$ at $\left.23^{\circ} \mathrm{C}\right) / 20 \mathrm{mM} \mathrm{MgCl}{ }_{2}$

Substrate oligonucleotide solution $(200 \mathrm{pmol} / \mu \mathrm{L})$

$100 \%$ ethanol, $-20^{\circ} \mathrm{C}$

TE buffer, pH 7.5 at $23^{\circ} \mathrm{C}$ (APPENDIX $\left.2 A\right)$

10× 3SR buffer: $500 \mathrm{mM}$ Tris. $\mathrm{Cl}\left(\right.$ APPENDIX $2 \mathrm{~A} ; \mathrm{pH} 7.5$ at $\left.23^{\circ} \mathrm{C}\right) / 100 \mathrm{mM} \mathrm{MgCl} / 20$ $\mathrm{mM}$ dithiothreitol (DTT)

$10 \times 3$ SR NTP/dNTP mix: $20 \mathrm{mM}$ each of the four ribonucleoside- $5^{\prime}$-triphosphates and $2 \mathrm{mM}$ each of the four deoxyribonucleoside- $5^{\prime}$-triphosphates (see APPENDIX $2 A$ for details of NTP and dNTP preparation and storage)

DNA primer 1: complementary to the $3^{\prime}$ tail of the modified ribozymes (20 $\mathrm{pmol} / \mu \mathrm{L})$

DNA primer 2: homologous to the $5^{\prime}$ end of each ribozyme $(20 \mathrm{pmol} / \mu \mathrm{L})$

$50 \mathrm{U} / \mu \mathrm{L}$ T7 RNAP (New England Biolabs) 


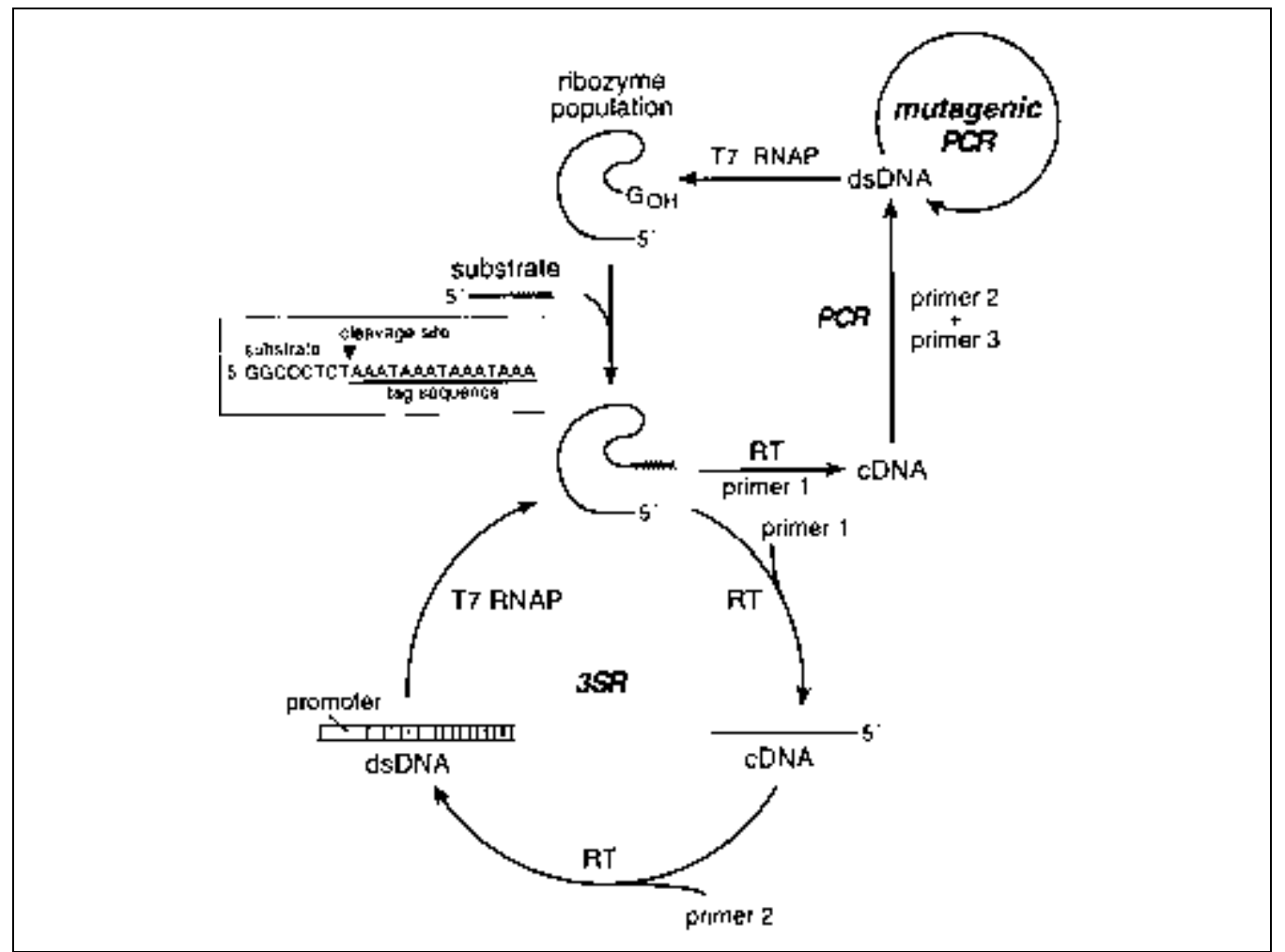

Figure 9.4.1 An in vitro selection scheme for the directed evolution of group I ribozymes. A pool of group I ribozyme variants (each carrying a $3^{\prime}$-terminal guanidyl residue) are incubated with a substrate oligonucleotide. Those ribozymes that catalyze the cleavage of the substrate via a phosphoester transfer reaction acquire a fragment of the substrate at their $3^{\prime}$ terminus. This oligonucleotide tail acts as a primer-binding site that tags the functional ribozyme variants for amplification by self-sustained sequence replication (3SR) using two primer DNAs (1 and 2). PCR is subsequently performed using a different set of DNA primers ( 2 and 3 ) that regenerate the desired $3^{\prime}$ terminus upon transcription of the resulting double-stranded DNA (dsDNA) template. Although the 3SR process is a significant source of mutations, additional sequence variation can be created through the use of mutagenic PCR (Support Protocol 1). T7 RNAP and RT represent T7 RNA polymerase and reverse transcriptase, respectively. Inset: sequence of substrate, including the tag sequence that is transferred to the $3^{\prime}$ terminus of the ribozyme upon cleavage.

$10 \mathrm{U} / \mu \mathrm{L}$ avian myoblastosis virus reverse transcriptase (AMV RT; Amersham)

\section{$0.3 \mathrm{~N} \mathrm{NaOH}$}

$3 \mathrm{M}$ sodium acetate, $\mathrm{pH} 5.2$ (APPENDIX 2A)

$10 \times$ PCR buffer: $100 \mathrm{mM}$ Tris. $\mathrm{Cl}\left(\mathrm{pH} 8.3\right.$ at $\left.23^{\circ} \mathrm{C}\right) / 15 \mathrm{mM} \mathrm{MgCl} / 2 / 500 \mathrm{mM}$ $\mathrm{KCl} / 0.1 \%(\mathrm{w} / \mathrm{v})$ gelatin

10× PCR dNTP mix: $2 \mathrm{mM}$ each of the four deoxyribonucleoside-5' - triphosphates (see APPENDIX $2 A$ for details of dNTP preparation and storage)

DNA primer 3: complementary to the original 3 ' terminus of the unmodified ribozymes $(20 \mathrm{pmol} / \mu \mathrm{L})$

5 U/ $\mu$ L Taq DNA polymerase (Boehringer Mannheim) diluted 20:1 in distilled $\mathrm{H}_{2} \mathrm{O}$ to $0.25 \mathrm{U} / \mu \mathrm{L}$ final concentration

Additional reagents and equipment for agarose gel electrophoresis (e.g., CPMB UNIT 2.5A) and DNA sequencing (APPENDIX $3 B$ )

\section{Perform the ribozyme reaction}

1. Prepare mutagenized RNA pool for group I ribozyme selection, at $10 \mathrm{pmol} / \mu \mathrm{L}$.

Combinatorial

Methods in

Nucleic Acid

Chemistry 
Due to its large size, starting pools for group I ribozyme selection cannot be prepared easily by chemical synthesis. However, there are several methods, such as mutagenic PCR or site-directed mutagenesis, that can be used for this purpose (see discussion above). Beaudry and Joyce (1992) made use of four mutagenic oligonucleotides that were used to form a pool of DNA templates that encode group I ribozyme variants. The mutations brought about by these oligonucleotides are located within the catalytic core of the ribozyme and were introduced at these locations to screen more efficiently for variant ribozymes with altered catalytic function. This protocol for the introduction of a specific level of sequence degeneracy over defined regions in DNA templates is described in detail elsewhere (Joyce and Inoue, 1989; Beaudry and Joyce, 1992). The resulting pool of DNA templates is transcribed in vitro using T7 RNAP (UNIT 9.3; Milligan and Uhlenbeck, 1989), and purified by polyacrylamide gel electrophoresis (APPENDIX 3B; Sambrook et al., 1989). Alternatively, mutagenic PCR (Support Protocol 1, Cadwell and Joyce, 1992) or hypermutagenic PCR (Vartanian et al., 1996) methods can be used to introduce mutations throughout the entire molecule.

2. Combine $100 \mu \mathrm{L}$ of $2 \times$ selection buffer, $70 \mu \mathrm{L}$ distilled water, and $20 \mu \mathrm{L}$ of 10 $\mathrm{pmol} / \mu \mathrm{L}$ ribozyme solution. Allow mixture to equilibrate several minutes at $37^{\circ} \mathrm{C}$.

3. Initiate the ribozyme reaction by the addition of $10 \mu \mathrm{L}$ of $200 \mathrm{pmol} / \mu \mathrm{L}$ substrate oligonucleotide. Incubate $1 \mathrm{hr}$ at $37^{\circ} \mathrm{C}$.

4. Precipitate the RNA by the addition of $500 \mu \mathrm{L}$ of $100 \%$ ethanol, $-20^{\circ} \mathrm{C}$. Pellet the precipitate by centrifugation for $15 \mathrm{~min}$ at $15,000 \times g, 4^{\circ} \mathrm{C}$. Resuspend the pelleted RNA in $20 \mu \mathrm{L}$ TE buffer.

During the first few rounds of selection it may be best to incubate the ribozyme reaction for extended times to allow suboptimal ribozymes greater opportunity to react. Because of the inherent mutagenic nature of the polymerase enzymes used for RNA and DNA amplification, or through the use of mutagenic PCR, the suboptimal ribozymes may acquire mutations that improve catalytic performance. In later rounds, reducing the reaction time will favor those ribozymes with faster catalytic rates. The time required to complete each round may vary as a result of alterations in the incubation times or of the intermittent use of accessory methods such as mutagenic PCR or additional purification steps. In practice, the completion of a single round of selection that includes the following amplification components requires 2 to 3 days.

\section{Selectively amplify by $3 S R$}

5. Combine $20 \mu \mathrm{L}$ resuspended pool RNA with the following reagents:

$35 \mu \mathrm{L}$ distilled $\mathrm{H}_{2} \mathrm{O}$

$10 \mu \mathrm{L} 10 \times 3 \mathrm{SR}$ buffer

$10 \mu \mathrm{L} 10 \times 3$ SR NTP/dNTP mix

$5 \mu \mathrm{L} 20 \mathrm{pmol} / \mu \mathrm{L}$ DNA primer 1

$5 \mu \mathrm{L} 20 \mathrm{pmol} / \mu \mathrm{L}$ DNA primer 2

$10 \mu \mathrm{L} 50 \mathrm{U} / \mu \mathrm{L}$ T7 RNAP

$5 \mu \mathrm{L} 10 \mathrm{U} / \mu \mathrm{L}$ AMV RT.

Selection for Catalytic Function with Nucleic Acids

Incubate mixture $1 \mathrm{hr}$ at $37^{\circ} \mathrm{C}$.

6. Terminate reaction by the addition of $10 \mu \mathrm{L}$ of $3 \mathrm{M}$ sodium acetate, $\mathrm{pH} 5.2$, and then precipitate the RNA/DNA mixture by the addition of $275 \mu \mathrm{L}$ of $100 \%$ ethanol, $-20^{\circ} \mathrm{C}$. Pellet the resulting nucleic acid precipitate by centrifugation as described in step 4 .

7. To destroy the remaining RNA, resuspend the resulting pellet in $200 \mu \mathrm{L}$ of $0.3 \mathrm{~N}$ $\mathrm{NaOH}$ and heat to $90^{\circ} \mathrm{C}$ for $10 \mathrm{~min}$. 
8. Precipitate the DNA by adding $20 \mu \mathrm{L}$ of $3 \mathrm{M}$ sodium acetate, $\mathrm{pH} 5.2$, and $550 \mu \mathrm{L}$ of $100 \%$ ethanol, $-20^{\circ} \mathrm{C}$, then pellet by centrifugation as described in step 4 . Resuspend the pelleted DNA in $20 \mu \mathrm{L}$ TE buffer.

\title{
Perform nested PCR amplification of cDNA
}

9. Combine $20 \mu \mathrm{L}$ cDNA with the following reagents:

\author{
$48 \mu \mathrm{L}$ distilled $\mathrm{H}_{2} \mathrm{O}$ \\ $10 \mu \mathrm{L} 10 \times$ PCR buffer \\ $10 \mu \mathrm{L} 10 \times$ PCR dNTP mix \\ $1 \mu \mathrm{L}$ DNA primer 2 \\ $1 \mu \mathrm{L}$ DNA primer 3 \\ $10 \mu \mathrm{L} 0.25 \mathrm{U} / \mu \mathrm{L}$ Taq DNA polymerase.
}

In order to restore the original untagged terminus of the RNA pool, cDNA products of the $3 S R$ reaction are amplified by PCR using a new DNA primer combination (primers 2 and 3). Primer 3 is complementary to the 3'-terminal bases of the ribozyme immediately preceding the tag sequence that was acquired during the preceding ribozyme reaction. This nested PCR reaction deletes the tag sequence and restores the guanosine residue required by the ribozyme for catalytic activity in the next selection cycle.

10. Perform up to 30 thermal cycles, each consisting of repetitive denaturing, annealing, and extension incubations (e.g., $30 \mathrm{sec}$ at $92^{\circ} \mathrm{C}, 30 \mathrm{sec}$ at $45^{\circ} \mathrm{C}, 30 \mathrm{sec}$ at $72^{\circ} \mathrm{C}$ ).

Optimal temperatures and incubation times must be established for different template and primer combinations.

11. Analyze the PCR products by agarose gel electrophoresis (e.g., Sambrook et al., 1989, or $C P M B$ UNIT 2.5A) to confirm the presence of template DNA.

12. The resulting double-stranded DNA is now ready to be transcribed (Milligan and Uhlenbeck, 1989; see also UNIT 9.3) to create the RNA pool for the next round of selection, thereby completing the selective-amplification cycle. Alternatively, the DNA can be cloned and sequenced (APPENDIX $3 B$ ) in order to examine individual RNAs that populate the selected pool.

\section{MUTAGENIC PCR}

Nucleic acid amplification processes such as RNA polymerization, reverse transcription, and the polymerase chain reaction unavoidably mutagenic, and therefore facilitate the accumulation of genetic diversity as in vitro selection progresses. However, in most cases it is beneficial to increase the frequency of mutations that are being introduced into the population in order to more rapidly and thoroughly explore sequence variations. The following support protocol provides a substantial increase in the error rate of DNA synthesis during the polymerase chain reaction. This protocol provides a mutation rate of approximately $0.7 \%$ per position with no strong bias for base substitutions. However, variation of the reaction conditions, particularly the concentrations of manganese and the relative concentrations of the dNTPs can significantly affect the mutagenic character of the reaction. The following protocol for mutagenic PCR is adapted from Cadwell and Joyce, 1992.

\section{Materials}

DNA Primer 2: homologous to the $5^{\prime}$ end of each ribozyme $(20 \mathrm{pmol} / \mu \mathrm{L})$

DNA Primer 3: complementary to the original $3^{\prime}$ terminus of the unmodified ribozymes $(20 \mathrm{pmol} / \mu \mathrm{L})$

DNA template: 5 pmole $/ \mu \mathrm{L}$ 
$10 \times$ mutagenic PCR buffer: $100 \mathrm{mM}$ Tris $\bullet \mathrm{Cl}\left(\mathrm{pH} 8.3\right.$ at $\left.23^{\circ} \mathrm{C}\right) / 70 \mathrm{mM} \mathrm{MgCl} \mathrm{m}_{2} / 500$ $\mathrm{mM} \mathrm{KCl} / 0.1 \%(\mathrm{w} / \mathrm{v})$ gelatin

$10 \times$ mutagenic PCR dNTP mix: $2 \mathrm{mM}$ each of dGTP and dATP/10 mM each of $\mathrm{dCTP}$ and dTTP

$5 \mathrm{mM} \mathrm{MnCl} \mathrm{m}_{2}$

$5 \mathrm{U} / \mu \mathrm{L}$ Taq DNA polymerase (Boehringer Mannheim) diluted 20:1 in $\mathrm{dH}_{2} \mathrm{O}$ to $0.25 \mathrm{U} / \mu \mathrm{L}$ final concentration

1. Combine $4 \mu \mathrm{L}$ DNA template with the following reagents:

$54 \mu \mathrm{L}$ distilled $\mathrm{H} 2 \mathrm{O}$

$10 \mu \mathrm{L} 10 \times$ mutagenic PCR buffer

$10 \mu \mathrm{L} 10 \times$ mutagenic PCR dNTP mix

$1 \mu \mathrm{L}$ DNA Primer 2

$1 \mu \mathrm{L}$ DNA Primer 3

$10 \mu \mathrm{L} 5 \mathrm{mM} \mathrm{MnCl} \mathrm{M}_{2}$

$10 \mu \mathrm{L} 0.25 \mathrm{U} / \mu \mathrm{L}$ Taq DNA polymerase.

To prevent precipitation of reagents, the $\mathrm{MnCl}_{2}$ should be added just prior to the addition of Taq DNA polymerase and initiation of the reaction.

2. Perform up to 30 thermal cycles as described in step 10 of Basic Protocol 1. Analyze the products and transcribe RNA as described in steps 11 and 12 of Basic Protocol 1.

BASIC PROTOCOL 2

Selection for Catalytic Function with Nucleic Acids

\section{IN VITRO SELECTION OF RNASE P RIBOZYME VARIANTS}

Several groups have reported the use of RNase P for the in vitro selection of new or improved substrates (Yuan and Altman, 1994; Liu and Altman, 1994; Pan, 1995) or for the selection of variant ribozymes themselves (Frank et al., 1996; Frank and Pace, 1997). In the latter examples, a self-cleaving RNA system consisting of a ribozyme/substrate construct was generated to facilitate the separation of active from inactive ribozyme variants. Since RNase P catalyzes the hydrolysis of RNA substrates, in vitro selection schemes for this ribozyme cannot take advantage of a self-ligation reaction. In contrast, mutagenized populations of this construct, termed TP292 $\Delta$, are immobilized on a thiophilic column via a phosphorothioate nucleotide attached to each RNA molecule (Fig. 9.4.2). Separation of active TP292 $\Delta$ variants is achieved upon RNA self-cleavage, which liberates ribozymes from the matrix - a process that has been termed "catalytic elution" (Breaker, 1997a). As a result of the specific methods used for this selection, specific changes must be made to the conventional protocols for RNA preparation and manipulation; these alterations are highlighted in the protocol given here. This procedure, adapted from Frank et al. (1996), can be broadly applied for the study of RNase P structure and function using in vitro selection.

In vitro transcription must be carried out under specialized conditions in order to include the $5^{\prime}$-thiophosphate moiety and to minimize the fraction of precursor RNAs that undergo self cleavage prior to the selection phase of the process. The efficiency of RNA transcription by T7 RNAP is substantially improved for templates that encode for the presence of a 5'-terminal guanosine nucleotide in the RNA transcript. As a result, different chemical groups can be incorporated into RNA during the transcription process if modified guanosine nucleotides are included in the reaction. This fact is exploited here to create pool RNAs that begin with a $5^{\prime}$-phosphorothioate residue. The in vitro transcription protocol is an adaptation of that described by Milligan and Uhlenbeck (1989) for the enzymatic synthesis of RNA. 


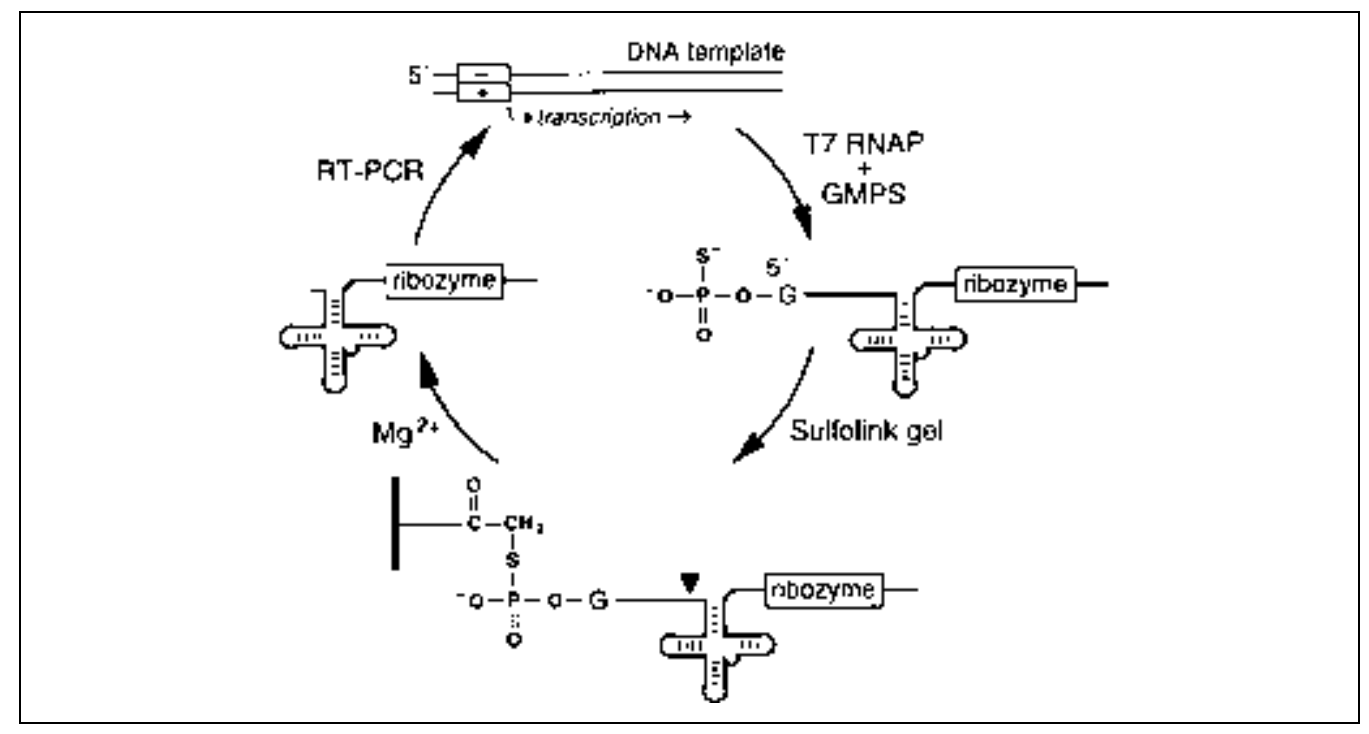

Figure 9.4.2 A selective-amplification strategy for the isolation of RNase $P$ ribozyme variants. A pool of double-stranded DNA templates that encode for TP292 $\Delta$ variants is transcribed in vitro using T7 RNA polymerase (T7 RNAP) in the presence of 5'-guanosine monophosphorothioate (GMPS). The resulting RNA pool is immobilized on a thiophilic beaded-agarose matrix. Competent variants of the ribozyme-substrate fusion are recovered from the matrix under permissive reaction conditions (added $\mathrm{Mg}^{2+}$ ) and amplified by RT-PCR. The cycle is repeated until RNAs with the desired activity dominate the amplified population. (-) and (+) represent the T7 RNAP promoter sequences that reside on the nontemplate and template strands, respectively. Shaded box represents the agarose matrix. Arrowhead identifies the site of ribozyme cleavage.

\section{Materials}

$10 \times$ transcription buffer (see recipe)

$10 \times$ transcription NTP mix: $10 \mathrm{mM}$ each of the four ribonucleoside- $5^{\prime}$-triphosphates

$50 \%(\mathrm{v} / \mathrm{v})$ aqueous glycerol

Double-stranded template DNA (at $10 \mathrm{pmol} / \mu \mathrm{L}$ )

100 mM guanosine-5'-phosphorothioate (GMPS; Amersham Life

Sciences-NucleixPlus)

$10 \mathrm{mCi} / \mathrm{mL}\left[\alpha_{-}{ }^{32} \mathrm{P}\right] \mathrm{GTP}(3000 \mathrm{Ci} / \mathrm{mmol})$

$50 \mathrm{U} / \mu \mathrm{L}$ T7 RNAP (New England Biolabs)

0.5 M EDTA, pH 8.0 (APPENDIX 2A)

$100 \%$ ethanol, $-20^{\circ} \mathrm{C}$

$2 \times$ urea loading buffer (APPENDIX 2A)

Gel elution buffer (see recipe)

TE buffer, $\mathrm{pH} 7.5$ (APPENDIX 2A)

Sulfolink gel (aqueous slurry of beaded agarose; Pierce)

Loading buffer: $40 \%$ methanol/20 mM sodium phosphate (pH 8.9)/0.1\% SDS (APPENDIX 2A)/5 mM EDTA

Nonpool RNAs: e.g., Bacillus subtilis rRNA

Wash buffer: $3 \mathrm{M} \mathrm{NaCl} / 50 \mathrm{mM}$ Tris. $\mathrm{Cl}$ (pH 8; APPENDIX 2A)/5 mM EDTA

Reaction buffer $-\mathrm{Mg}^{2+}$ (see recipe)

$1 \mathrm{M} \mathrm{MgCl}_{2}$

Glycogen

Sterile razor blade

Liquid scintillation counter

Combinatorial

Methods in

Nucleic Acid

Chemistry 
Additional reagents and equipment for denaturing polyacrylamide gel

electrophoresis (PAGE; e.g., APPENDIX $3 B$ or CPMB UNIT 7.6) and RT-PCR (UNIT 9.3)

\section{Perform in vitro transcription}

1. Combine in a $1.5-\mathrm{mL}$ microcentrifuge tube (100 $\mu$ l total volume):

$30.5 \mu \mathrm{L}$ distilled $\mathrm{H}_{2} \mathrm{O}$

$10 \mu \mathrm{L} 10 \times$ transcription buffer

$10 \mu \mathrm{L} 10 \times$ transcription NTP mix

$15 \mu \mathrm{L} 50 \%$ aqueous glycerol

$2 \mu \mathrm{L} 10 \mathrm{pmol} / \mu \mathrm{L}$ template DNA

$7.5 \mu \mathrm{L} 100 \mathrm{mM}$ GMPS

$5 \mu \mathrm{L} 10 \mathrm{mCi} / \mathrm{mL}\left[\alpha_{-}{ }^{32} \mathrm{P}\right] \mathrm{GTP}$

$20 \mu \mathrm{L} 50 \mathrm{U} / \mu \mathrm{L}$ T7 RNAP.

Incubate mixture $12 \mathrm{hr}$ at $12^{\circ} \mathrm{C}$.

2. Terminate reaction by the addition of $3 \mu \mathrm{L}$ of $0.5 \mathrm{M}$ EDTA, $\mathrm{pH} 8.0$.

3. Recover the resulting RNA products by precipitation with $250 \mu \mathrm{L}$ of $100 \%$ ethanol at $-20^{\circ} \mathrm{C}$, centrifuge as described in step 4 of Basic Protocol 1, and resuspend the pelleted RNA in $40 \mu \mathrm{L}$ of $2 \times$ urea loading buffer.

Preparation of the RNA pool differs in two main ways from the method described previously (Milligan and Uhlenbeck, 1989). First, an excess (7.5:1 ratio) of GMPS to GTP is used to favor the incorporation of the thiophosphate-containing nucleotide at the start of most transcripts. Second, in vitro transcription is conducted under reduced temperature in order to minimize cleavage (and loss) of functional ribozymes during preparation. The RNase $P$ ribozyme, like most catalytic nucleic acids, requires $\mathrm{Mg}^{2+}$ to display catalytic function. As a result, it is important to terminate the transcription reaction with EDTA to preclude continuing self cleavage of the RNA products.

\section{Gel purify RNA transcription products}

4. Separate the transcription products on a $5 \%$ denaturing polyacrylamide gel (e.g., APPENDIX $3 B$ Or CPMB UNIT 7.6).

5. Visualize the RNA precursor band by UV shadowing or autoradiography, and excise using a sterile razor blade.

6. Recover the isolated RNAs by crush/soaking the gel overnight at $4{ }^{\circ} \mathrm{C}$ in gel elution buffer.

7. Precipitate recovered RNAs by the addition of $2.5 \mathrm{vol}$ of $100 \%$ ethanol, $-20^{\circ} \mathrm{C}$, and pellet by centrifugation as described in step 4 of Basic Protocol 1.

8. Resuspend pelleted RNA in TE buffer, quantitate by liquid scintillation counting, and store at $-20^{\circ} \mathrm{C}$.

\section{Perform ribozyme selection and amplification}

9. Place $150 \mu \mathrm{L}$ of Sulfolink gel slurry in a $1.5-\mathrm{mL}$ microcentrifuge tube, add $300 \mu \mathrm{L}$ loading buffer, and swirl to wash the beads. Pellet beads by brief centrifugation. Repeat for total of three washes.

Selection for Catalytic Function with Nucleic Acids
10. Cover the beads with $300 \mu \mathrm{L}$ loading buffer containing $16 \mu \mathrm{g}$ Bacillus subtilis rRNA (or other nonpool RNA) and let stand $45 \mathrm{~min}$ at $25^{\circ} \mathrm{C}$.

This prebinding serves to occupy nonspecific RNA binding sites on the agarose matrix. 
11. To refold RNAs, preincubate $100 \mathrm{pmol} 5^{\prime}$-thiophosphate-terminated RNA molecules (from step 8) in $300 \mu \mathrm{L}$ loading buffer for $3 \mathrm{~min}$ at $65^{\circ} \mathrm{C}$, then for $1 \mathrm{~min}$ at $50^{\circ} \mathrm{C}$.

12. Combine washed gel beads and preincubated RNA solution, and incubate 1 to $2 \mathrm{hr}$ at room temperature.

13. Remove unbound RNAs from the matrix with four successive washes each using 300 $\mu \mathrm{L}$ wash buffer as described in step 9 , followed by four additional washes each using $300 \mu \mathrm{L}$ reaction buffer $-\mathrm{Mg}^{2+}$.

14. Resuspend the final washed RNA/bead slurry in $225 \mu \mathrm{L}$ reaction buffer $-\mathrm{Mg}^{2+}$, giving a total volume of $\sim 370 \mu \mathrm{l}$. Allow the mixture to equilibrate at $50^{\circ} \mathrm{C}$ for $1 \mathrm{~min}$. Initiate reactions by the addition of $9 \mu \mathrm{L}$ of $1 \mathrm{M} \mathrm{MgCl}_{2}$ (giving a final concentration of $\sim 25$ $\mathrm{mM}$ cofactor).

15. After the desired incubation time, terminate reaction by the addition of $30 \mu \mathrm{L}$ EDTA.

16. Add $5 \mu \mathrm{g}$ glycogen, then precipitate with ethanol as described in step 4 of Basic Protocol 1 to recover the ribozymes.

The glycogen aids in precipitating even small amounts of RNA.

17. Resuspend the resulting pellet in $25 \mu \mathrm{L}$ TE buffer.

18. Use the RNAs as a substrate for RT-PCR using appropriate DNA oligomers (to convert the RNAs into cDNA and amplify them; see UNIT 9.3 for RT-PCR procedure).

The entire protocol, beginning with in vitro transcription, is repeated in an iterative fashion until satisfactory catalytic activity is observed with the RNA pool. Molecules present in the final pool are cloned and sequenced to facilitate further analysis of the resulting ribozyme variants.

\section{IN VITRO SELECTION OF NEW KINASE RIBOZYMES FROM RANDOM SEQUENCE}

Due to the enormous numbers of oligonucleotides that can be screened simultaneously by in vitro selection, it is practical to isolate entirely new and complex ribozymes from random-sequence pools. This was first demonstrated by Bartel and Szostak (1993), who isolated a series of "ligase" ribozymes from a large pool of random-sequence RNAs. Lorsch and Szostak (1994) expanded on this approach by creating a biased pool that carried both random-sequence and preexisting functional RNA domains in their successful search for "kinase" ribozymes (Fig. 9.4.3). The selection protocol for the latter study is described below.

\section{Materials}

$2 \times$ kinase selection buffer (see recipe)

$100 \mathrm{mM}$ adenosine $5^{\prime}-O$-(3-thiotriphosphate) (ATP- $\gamma \mathrm{S}$; Sigma)

$100 \%$ ethanol, $-20^{\circ} \mathrm{C}$

Binding buffer: $1 \mathrm{mM}$ EDTA/25 mM HEPES (pH 7.4 at $23^{\circ} \mathrm{C}$ )

Thiopyridine-activated thiopropyl Sepharose 6B (Amersham Pharmacia Biotech)

Wash buffer: $1 \mathrm{M} \mathrm{NaCl} / 5 \mathrm{mM}$ EDTA/25 mM HEPES (pH 7.4 at $23^{\circ} \mathrm{C}$ )

Urea solution: $3 \mathrm{M}$ urea/5 mM EDTA

$0.1 \mathrm{M}$ 2-mercaptoethanol

$3 \mathrm{M}$ sodium acetate, $\mathrm{pH} 5.2$ (APPENDIX 2A)

Chromatographic column 


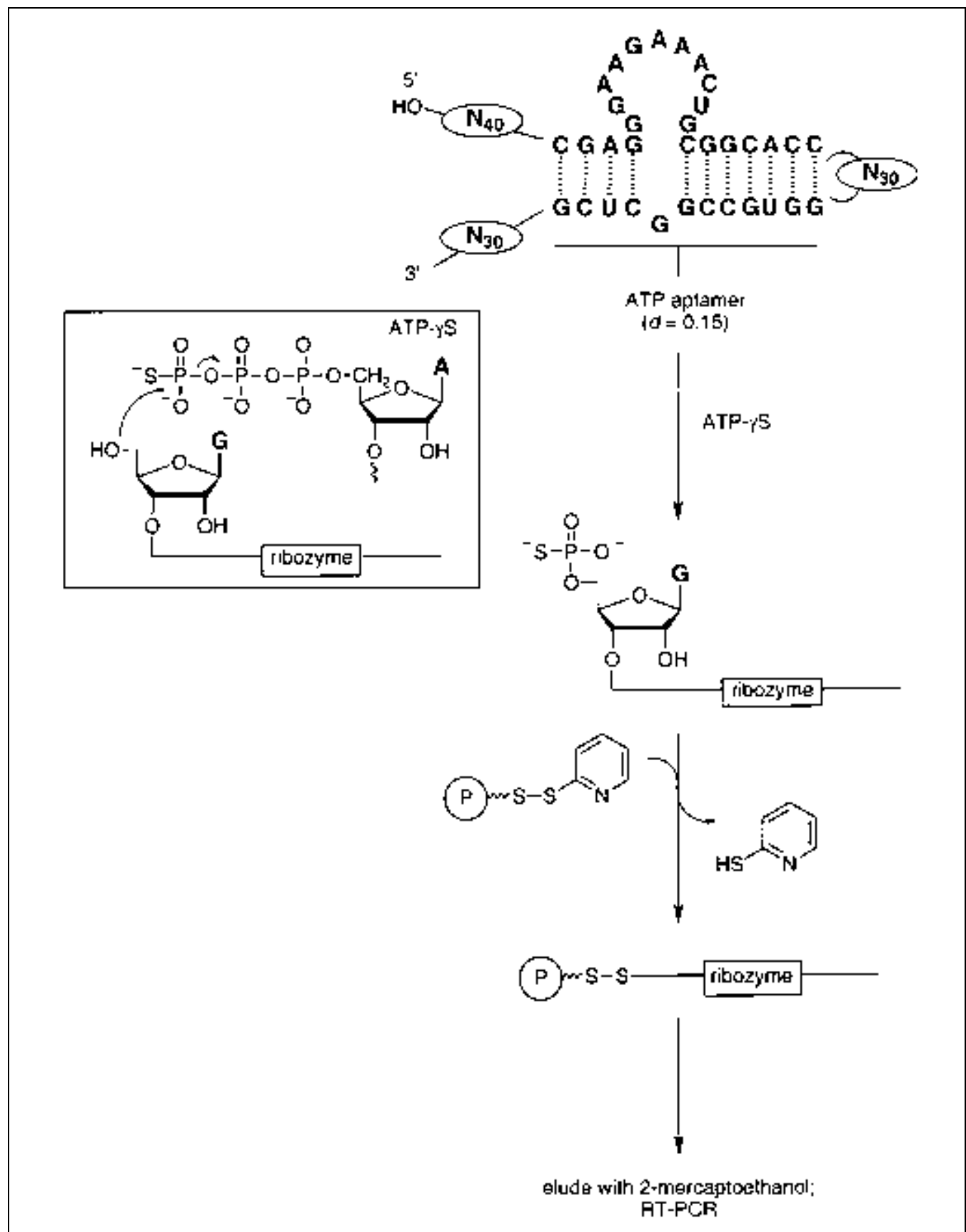

Figure 9.4.3 Scheme for the isolation of self-phosphorylating ribozymes from a biased RNA pool that includes random-sequence domains. The pool is composed of three regions of random nucleotide sequence that are intermixed with a mutagenized ( $d=0.15$; Breaker and Joyce, 1994a) ATP-binding domain. Pool RNAs must be dephosphorylated each round to remove the 5 'triphosphate moiety that results from preparative in vitro transcription. RNAs that acquire the thiophosphate moiety of ATP- $\gamma S$ in the selection reaction (inset) are selectively captured by a thiophilic resin. RNAs bound by the resulting disulfide bond are specifically eluted with 2-mercaptoethanol and are amplified by RT-PCR. The variable $d$ represents the nucleotide degeneracy at each of the specified positions in the polynucleotide chain (e.g. $d=0.15$ reflects a 0.85 probability of finding the wild-type

Selection for Catalytic Function with Nucleic Acids nucleotide and a 0.15 probability of finding one of the three remaining nucleotides at a given position). 
1. Prepare mutagenized RNA pool for kinase ribozyme selection, at $20 \mathrm{pmol} / \mu \mathrm{L}$.

In the original study reported by Lorsch and Szostak (1994), a mutagenized ATP-binding domain was integrated with random-sequence domains to create the RNA pool. Briefly, two synthetic DNAs that correspond to the two halves of the final RNA pool (Fig. 9.4.3) were made double stranded by PCR, treated with the restriction enzyme BanI, and joined using T4 DNA ligase. The ligated pool of DNA templates was transcribed in vitro using T7 RNAP, and the resulting pool of RNA transcripts was purified by polyacrylamide gel electrophoresis. At this stage, each RNA molecule carried a 5'-terminal triphosphate moiety that would block autophosphorylation at this position. Therefore, the RNA pool was treated exhaustively with alkaline phosphatase prior to the selection reaction in order to generate RNA precursors each carrying a hydroxyl group at their $5^{\prime}$ terminus. Alternatively, a pool composed exclusively of random-sequence RNAs can be prepared (see UNIT 9.2).

2. Combine $500 \mu \mathrm{L}$ of $2 \times$ selection buffer, $440 \mu \mathrm{L}$ distilled water, and $50 \mu \mathrm{L}$ of 20 $\mathrm{pmol} / \mu \mathrm{L}$ pool RNA solution. Allow mixture to equilibrate at $23^{\circ} \mathrm{C}$ for several minutes.

3. Initiate the ribozyme reaction by the addition of $10 \mu \mathrm{L}$ ATP- $\gamma \mathrm{S}$ and incubate $20 \mathrm{hr}$ at $23^{\circ} \mathrm{C}$.

4. Precipitate the RNA by the addition of $2.5 \mathrm{~mL}$ of $100 \%$ ethanol, $-20^{\circ} \mathrm{C}$, followed by centrifugation as described in step 4 of Basic Protocol 1. Resuspend the pelleted RNA in $500 \mu \mathrm{L}$ binding buffer.

5. Combine the RNA solution with an equal volume of a slurry of the activated thiopropyl Sepharose and incubate $30 \mathrm{~min}$ at $23^{\circ} \mathrm{C}$.

6. Prepare a column (e.g. $0.8 \times 4 \mathrm{~cm}$ poly-prep., Bio-Rad) with the RNA/Sepharose mixture. Remove unbound RNAs from the matrix by washing with 20 bed volumes each of wash buffer, distilled $\mathrm{H}_{2} \mathrm{O}$, and urea solution.

7. Elute disulfide-linked RNAs with 1 column volume 0.1 M 2-mercaptoethanol.

8. Add $3 \mathrm{M}$ sodium acetate, $\mathrm{pH} 5.2$, to the recovered RNA solution to give a final concentration of $0.3 \mathrm{M}$. Precipitate the RNA by the addition of $2.5 \mathrm{vol}$ of $100 \%$ ethanol, $-20^{\circ} \mathrm{C}$, followed by centrifugation as described in step 4 of Basic Protocol 1 .

As stated in Basic Protocol 1, during the first few rounds of selection it may be best to incubate the ribozyme reaction for extended times to allow suboptimal ribozymes greater opportunity to react. In later rounds, reducing the reaction time will favor those ribozymes with faster catalytic rates. Other reaction conditions, such as concentrations of ATP- $\gamma S$ or divalent metal ions, can be adjusted to favor ribozymes that have greater affinities for these agents.

\section{CONTINUOUS EVOLUTION OF LIGASE RIBOZYMES}

A new method for the continuous evolution of ribozymes has proven to be a powerful means to isolate ligase ribozyme variants with modified catalytic activity. Continuous evolution is a dynamic process whereby ribozymes that best serve as catalysts and as templates for cDNA synthesis and RNA transcription dominate the population of amplifying RNAs. Therefore, any variations in the catalysis and amplification cycle can be made so long as the protein enzymes that facilitate RNA and DNA synthesis are not rendered inactive. Outlined below is a protocol used by Wright and Joyce (1997) to propagate variants of RNA ligase ribozymes.

BASIC

PROTOCOL 4

Combinatorial

Methods in

Nucleic Acid

Chemistry 


\title{
Materials
}

$10 \times$ reaction buffer (see recipe)

$10 \times 3$ SR NTP/dNTP mix: $20 \mathrm{mM}$ each of the four ribonucleoside- $5^{\prime}$-triphosphates and $2 \mathrm{mM}$ each of the four deoxyribonucleoside-5'-triphosphates (see APPENDIX $2 A$ for NTP and dNTP preparation details)

DNA primer 1: complementary to the $3^{\prime}$ tail of the pool RNAs $(20 \mathrm{pmol} / \mu \mathrm{L})$

Substrate oligonucleotide: DNA/RNA chimera that encodes the T7 promoter sequence $(20 \mathrm{pmol} / \mu \mathrm{L})$

40 U/ $\mu$ L T7 RNAP (New England Biolabs)

$200 \mathrm{U} / \mu \mathrm{L}$ Moloney murine leukemia virus reverse transcriptase (MMLV RT; Amersham)

1. Prepare mutagenized RNA pool for continuous evolution.

Initial pools for the first round of continuous evolution can be prepared by in vitro transcription from synthetic DNAs (mutagenized during chemical synthesis) or from DNA templates that resulted from RT-PCR amplification of the selected ribozymes (see UNIT 9.3). A primary concern when initiating the continuous evolution experiment is the catalytic speed of the starting ribozyme. The prototype ribozyme used by Wright and Joyce (1997) to generate the starting RNA pool for their RNA ligase selection experiment was an inefficient catalyst that could not compete successfully with selfish RNAs. As a result, the authors subjected a pool of $10^{14}$ ribozyme variants to several conventional rounds of in vitro selection followed by an intermediate form of continuous evolution to enrich the RNA population with highly active ribozymes. This more efficient population of ribozymes subsequently was used to initiate the continuous evolution process. Similarly, individual ribozymes that meet this activity threshold must be present in the starting RNA population in order to initiate the continuous evolution process.

2. Combine in a $1.5-\mathrm{mL}$ microcentrifuge tube $(20 \mu \mathrm{L}$ total volume):

\author{
$5.5 \mu \mathrm{L}$ distilled $\mathrm{H}_{2} \mathrm{O}$ \\ $1 \mu \mathrm{L}$ pool RNA \\ $2 \mu \mathrm{L} 10 \times$ reaction buffer \\ $2 \mu \mathrm{L} 10 \times 3$ SR NTP/dNTP mix \\ $2.5 \mu \mathrm{L} 20 \mathrm{pmol} / \mu \mathrm{L}$ DNA primer 1 \\ $5 \mu \mathrm{L} 20 \mathrm{pmol} / \mu \mathrm{L}$ substrate oligonucleotide \\ $1 \mu \mathrm{L} 40 \mathrm{U} / \mu \mathrm{L}$ T7 RNAP \\ $1 \mu \mathrm{L} 200 \mathrm{U} / \mu \mathrm{L}$ MMLV RT.
}

Selection for Catalytic Function with Nucleic Acids

Incubate $1 \mathrm{hr}$ at $37^{\circ} \mathrm{C}$.

3. Dilute an aliquot of the reaction mixture 50-fold with distilled $\mathrm{H}_{2} \mathrm{O}$. Either proceed with the next serial transfer or store the diluted sample at $-20^{\circ} \mathrm{C}$ for future use.

Iterations involving serial dilution of the pool followed by repetition of the reaction can be carried out indefinitely. This continuous evolution format favors catalytic RNAs that perform the ligation reaction most rapidly. As the selective-amplification cycles proceed and the ribozymes become more efficient, stages of the cycle other than the catalytic step may become limiting to the overall process. Propagation of ribozyme variants that overcome whatever is the rate-limiting (catalytic or amplification) step will dominate the population of amplifying RNAs. This feature of continuous evolution could be exploited to examine the mechanisms and kinetics of nucleic acid amplification in addition to catalysis. 
REAGENTS AND SOLUTIONS

Use distilled, deionized water or other ultrapure water in all recipes and protocol steps. For common stock solutions, see APPENDIX 2A; for suppliers, see SUPPLIERS APPENDIX.

\section{Gel elution buffer}

$0.3 \mathrm{M}$ sodium acetate

$10 \mathrm{mM}$ Tris.Cl, pH $7.4($ APPENDIX 2A)

1 mM EDTA (APPENDIX 2A)

$0.5 \%(\mathrm{w} / \mathrm{w})$ sodium dodecyl sulfate (SDS; APPENDIX 2A)

Autoclave and store indefinitely at room temperature

\section{Reaction buffer for continuous evolution, 10×}

$500 \mathrm{mM}$ EPPS [4-(2-hydroxethyl)-1-piperazinepropanesulfonic acid], $\mathrm{pH} 8.5$ at $23^{\circ} \mathrm{C}$

$500 \mathrm{mM} \mathrm{KCl}$

$250 \mathrm{mM} \mathrm{MgCl}{ }_{2}$

$40 \mathrm{mM}$ dithiothreitol (DTT)

$20 \mathrm{mM}$ spermidine

Store indefinitely at $-20^{\circ} \mathrm{C}$

\section{Reaction buffer $-\mathrm{Mg}^{2+}$ (for ribozyme selection)}

$3 \mathrm{M}$ sodium acetate

$44.5 \mathrm{mM}$ Tris. $\mathrm{Cl}($ APPENDIX $2 A)$

$16 \mathrm{mM}$ piperazine- $N, N$ '-bis(2-hydroxypropanesulfonic acid) (PIPES)

$0.05 \%$ SDS (APPENDIX 2A)

Adjust $\mathrm{pH}$ to 8 with $\mathrm{NaOH}$

Store indefinitely at $-20^{\circ} \mathrm{C}$

Selection buffer, $2 \times$

$50 \mathrm{mM}$ HEPES ( $N$-2-hydroxyethylpiperazine- $N$ '-2-ethanesulfonic acid), $\mathrm{pH} 7.4$ at $23^{\circ} \mathrm{C}$

$100 \mathrm{mM} \mathrm{MgCl}{ }_{2}$

$10 \mathrm{mM} \mathrm{MnCl}_{2}$

$800 \mathrm{mM} \mathrm{KCl}$

Store indefinitely at $-20^{\circ} \mathrm{C}$

Transcription buffer for in vitro selection, 10 $\times$

$400 \mathrm{mM}$ Tris. $\mathrm{Cl}$ (APPENDIX 2A), $\mathrm{pH} 8.1$ at $37^{\circ} \mathrm{C}$

$60 \mathrm{mM} \mathrm{MgCl}_{2}$

$50 \mathrm{mM}$ DTT

$10 \mathrm{mM}$ spermidine

$0.1 \%(\mathrm{v} / \mathrm{v})$ Triton X-100

$50 \mu \mathrm{g} / \mathrm{mL}$ bovine serum albumin (BSA)

Store indefinitely at $-20^{\circ} \mathrm{C}$

\section{COMMENTARY}

\section{Background Information}

\section{Catalytic nucleic acids and in vitro selection}

An essential characteristic of any class of polymers that is capable of supporting diverse catalytic activity is the ability to form a nearly endless array of higher-ordered folding patterns. This structural sophistication allows the polymer to form precise active sites for specific binding of substrates and for catalysis of chemical transformations. Beginning with the determination of the three-dimensional structure of tRNA $^{\text {Phe }}$ (Kim et al., 1973; Robertus et al., 1974), it has become increasingly clear over the last two decades that RNA has enormous potential for forming unique secondary and tertiary structures (Gold et al., 1995; Osborne and Ellington, 1997). Evidence that this structural
Combinatorial Methods in Nucleic Acid Chemistry 
complexity could be exploited to form catalytic RNAs was first obtained upon the discovery of natural ribozymes that self splice (Kruger et al., 1982) and that function as RNA endonucleases (Guerrier-Takada et al., 1983). The collection of natural and artificial ribozymes has expanded rapidly in recent years to include a wide range of catalytic activities (Breaker, 1997a; Jaeger, 1997), providing strong support for the view that the structure-forming potential of RNA is more than adequate to allow the formation of a great diversity of ribozymes that carry precisely formed active sites.

The many examples of catalytic RNAs also provide compelling evidence for the notion that an "RNA world" may have preceded the protein-dominated metabolic processes that are in operation today (White, 1976; Gilbert, 1986; Cech, 1993; Benner et al., 1989). Although always a topic of debate, this theory has inspired many who study nucleic acids to aggressively seek new ribozymes that catalyze reactions believed to be central to the origin and evolutionary progression of life. In addition, researchers continue to probe the limits of biocatalysts both under cellular conditions and when the biochemical rules and reaction conditions are no longer set by living organisms. Even DNA can be forced to function as an enzyme outside the confines of living cells (Breaker, 1997b), suggesting that the perceived biological limitations for catalytic nucleic acids may be overcome simply by using the latest strategies for the design of novel nucleic acids.

Almost without exception, the search for new ribozymes and deoxyribozymes makes use of in vitro selection methods, which have proven to be the most effective approach for producing new or altered RNA catalysts (Breaker, 1997a). In vitro selection relies on the probability that only one or perhaps a few individuals amongst trillions of random-sequence molecules can promote the chemical reaction of interest. This process makes use of selection and amplification procedures that are performed repetitively to recover these rare catalysts from the pool of inactive molecules. Critical to the success of an in vitro selection experiment is the judicious design of the selection and amplification protocol. As with natural selection, these "test-tube evolution" experiments are unforgiving and can give rise to spurious products unless great care and forethought are given to the design of the experimental methodology (see UNIT 9.3 for further discussion on "molecular parasites"). Unfortunately, methods for the selection of catalytic
RNAs and DNAs must be revised for each new catalytic activity sought, each time forcing the careful reevaluation of the protocols to be employed.

Given the expected functional diversity of RNA and DNA, a wide range of chemical and molecular biological techniques will be needed to successfully and efficiently expand the catalytic repertoire of nucleic acids. The protocols described herein are representative of the many existing methods that have been used successfully to isolate ribozymes with new or improved catalytic function. Future efforts in this field no doubt will expand the catalytic repertoire of RNA and DNA, probe the limits of function with existing catalysts, and create superior RNA and DNA catalysts that have utility beyond basic science. Whether the experimenter's specific goal is to identify new classes of catalytic nucleic acids, or to focus the selection pressure precisely on a individual kinetic parameter of an existing enzyme, new or modified selection strategies and methods most likely will need to be devised.

\section{Early selection experiments with group I ribozymes}

One of the first ribozymes to be subjected to in vitro selection is the group I self-splicing ribozyme. This ribozyme forms an intron of the $26 \mathrm{~S}$ ribosomal RNA precursor from the ciliated protozoan Tetrahymena thermophila, which is known to self process (Kruger et al., 1982). The Tetrahymena ribozyme has been used as a starting point for a number of pioneering in vitro selection experiments that tested the methods, possible strategies, and the limitations of different selective-amplification processes. Although this ribozyme normally promotes two successive RNA phosphoester transfer reactions that produce spliced exons, reorganized forms of the enzyme have been made to catalyze several related reactions including RNA cleavage, oligonucleotide polymerization/depolymerization, and dephosphorylation reactions (Cech, 1990). More recently, in vitro selection has been used to isolate variants of group I ribozymes that have new functions such as DNA cleavage (Beaudry and Joyce, 1992; Tsang and Joyce, 1996) and altered metal-ion dependence (Lehman and Joyce, 1993), or that have new or altered structural domains (e.g., Green et al., 1990; Williams et al., 1994; Costa and Michel, 1997). Similar investigations are now being conducted with other large ribozymes. 


\section{Continuous evolution of ribozymes}

Most in vitro selection experiments proceed in a punctuated fashion, meaning that the experimenter must actively participate in the selection process through manual intervention or automated processing. For example, the selection and amplification steps of most simulated evolutionary processes each require time-consuming manipulations such as gel purification, column chromatography, gel elution, nucleic acid precipitation, or separate enzyme reactions for the amplification of selected products. Without this intervention the selection process would cease and only a portion of a given round of selection would be completed. Depending on the complexity of the selection process, this demand for manipulation adds days or weeks to the time that the catalytic molecules actually are performing as catalysts, and these manipulations can become annoyingly repetitive.

For one class of reactions at least, this process has been simplified by employing a selective-amplification method that almost completely eliminates the need for experimenter intervention. "Continuous evolution" of catalytic RNA function has been demonstrated (Wright and Joyce, 1997) using a variant of the ligase ribozymes isolated by Bartel and Szostak (1993). This scheme (Fig. 9.4.4) was designed to couple the catalysis and amplification processes in order to create a self-sustaining system whereby the fastest ribozymes become available for selective amplification sooner than their molecular competitors (Breaker and Joyce, 1994b). The resulting amplification process creates molecular progeny molecules that again need to promote the ligation reaction in order to replicate. Infinite cycles of coupled selection and amplification can proceed in a continuous fashion using a serial transfer procedure, whereby a portion of the preceding reaction is used to initiate a fresh reaction mixture. Coupled catalysis and amplification processes, however, are prone to the generation of selfish nucleic acids that replicate without the need for catalysis (Breaker and Joyce, 1994; Breaker et al., 1994). Therefore great care must be taken to prevent these molecules from overtaking the RNA population.

\section{Critical Parameters}

There are an almost overwhelming number of issues that must be considered when initiating an in vitro selection project. Unfortunately, how many of these critical parameters should be addressed will change depending on the goals of the project. Of foremost importance is

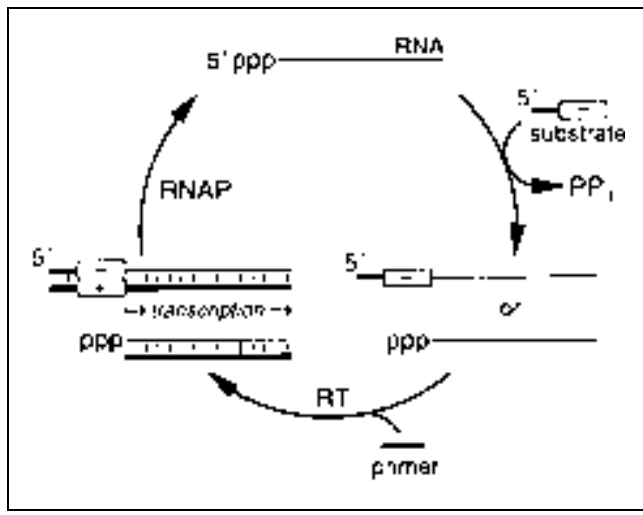

Figure 9.4.4 Scheme for the continuous in vitro evolution of ligase ribozymes. A mutagenized population of self-ligating ribozymes is incubated in the presence of reverse transcriptase (RT), RNA polymerase (RNAP), and oligonucleotide substrate. Functional ribozymes in this mixture undergo a sequence of ribozyme- and protein enzyme-mediated reactions in order to replicate. RNAs that catalyze the formation of a new $3^{\prime}-5^{\prime}$ linkage to a substrate oligonucleotide (at the expense of the 5 -terminal triphosphate moiety) acquire a promoter sequence that is specific for the constituent RNA polymerase. Upon reverse transcription, the chimeric RNA-DNA hybrids formed from active ribozymes now carry a double-stranded promoter element. RNA polymerase initiates transcription form this double-stranded sequence, producing new RNA enzymes each with a regenerated 5'triphosphate terminus. These new RNAs, some of which carry new mutations as a result of the inherent infidelity of the polymerizing enzymes, can participate in the next round of selective amplification.

the catalytic activity sought by the researcher. For example, one may want to have some confidence that molecules within the pool can catalyze the target reaction before committing time and resources to an in vitro selection effort. In many cases, in vitro selection is limited to isolating catalysts with a rate constant of at least $10^{-5} \mathrm{~min}^{-1}$ — which equates to a half life for the precursor of $\sim 5$ days for self-modifying enzymes. To effectively isolate enzymes with poorer rate constants, even longer incubation times for the selection would be necessary to allow a significant number of enzymes to react. In addition, most catalysts isolated from random-sequence pools catalyze the target reaction with rates that are $<1$-million-fold above the equivalent uncatalyzed reaction, although in many instances additional rounds of mutation and selection do result in greater rate en-
Combinatorial Methods in Nucleic Acid Chemistry 
hancements. Therefore, targeting a reaction that has a rate constant for the uncatalyzed reaction of $10^{-11}$ or lower is expected to be very challenging.

In general, maximizing both the pool diversity and the size of the mutagenized domains will increase the probability that the catalysts of interest will be represented. However, these parameters must be balanced with practical considerations such as the ease and expense of pool construction and the technical challenges posed by the amplification and manipulation of larger oligonucleotide constructs. The introduction of mutations into preexisting ribozymes is also of great importance. Too small a number of mutations will not allow sampling of ribozyme variants that have the catalytic parameters of interest, while too large a number of mutations may create variant that are so distant from the original ribozyme that entirely new catalytic motifs with the same catalytic function will be isolated.

Extreme care must be exercised during all stages of the selection protocol, as most technical problems can result in a reduction of the sequence diversity comprising the pool. This is particularly important during the early stages of any selection project. In many cases, a catalytic "signal" from the population that could be used to confirm satisfactory progress may not appear until several rounds of selection have been completed. Since many in vitro selection protocols are assembled using routine molecular biology techniques, precautions used to ensure success with these techniques should be exercised faithfully throughout the entire selection process.

\section{Anticipated Results}

If successful, a typical in vitro selection protocol yields a population of functional molecules within three to ten rounds of selective amplification. The exact performance of each selection experiment will depend upon a number of factors, such as the frequency of active molecules in the original pool and the stringency of the selection process. However, it must be noted that $\sim 50 \%$ of all reported ribozyme-selection experiments to date have yielded molecules that survive the selection protocol by some mechanism other than that originally intended by the investigators. These unexpected "answers" range from simple "molecular parasites" that do not perform chemical reactions, to catalysts that promote reactions that are distinct from the desired reaction. If these undesirable molecules emerge during in vitro selection, each must be assessed and dealt with on an individual basis given the innumerable possible mechanisms by which they may survive.

\section{Time Considerations}

The time required to successfully complete an in vitro selection experiment will vary widely depending on the complexity of the selection protocol and on the challenge of the reaction that is presented to the pool of molecules. Most of the standard molecular biology techniques typically used when assembling selection protocols can be completed within several hours. However, more complicated in vitro selection protocols may be comprised of a dozen or more techniques for each round that together may require several days to complete. For most in vitro selection efforts, the researcher should be prepared to devote several months to the selection phase of the study.

\section{Literature Cited}

Bartel, D.P. and Szostak, J.W. 1993. Isolation of new ribozymes from a large pool of random sequences. Science 261:1411-1418.

Beaudry, A.A. and Joyce, G.F. 1992. Directed evolution of an RNA enzyme. Science 257:635-641.

Benner, S.A., Ellington, A.D., and Tauer, A. 1989. Modern metabolism as a palimpsest of the RNA world. Proc. Natl. Acad. Sci. U.S.A. 86:70547058.

Breaker, R.R. and Joyce, G.F. 1994a. Inventing and improving ribozyme function: rational design versus iterative selection methods. Trends Biotechnol. 12:268-275.

Breaker, R.R and Joyce, G.F. 1994b. Emergence of a replicating species from an in vitro RNA evolution reaction. Proc. Natl. Acad. Sci. U.S.A. 91:6093-6097.

Breaker, R.R., Banerji, A., and Joyce, G.F. 1996. Continuous in vitro evolution of bacteriophage RNA polymerase promoters. Biochemistry 33:11980-11986.

Breaker, R.R. 1997a. In vitro selection of catalytic polynucleotides. Chem. Rev. 97:371-390.

Breaker, R.R. 1997b. DNA aptamers and DNA enzymes. Curr. Opin. Chem. Biol. 1:26-31.

Cadwell, R.C. and Joyce, G.F. 1992. Randomization of genes by PCR mutagenesis. PCR Methods Appl. 2:28-33.

Cech, T.R. 1990. Self-splicing of group I introns. Annu. Rev. Biochem. 59:543-568.

Cech, T.R. 1993. The efficiency and versatility of catalytic RNA: Implications for an RNA world. Gene 135:33-36. 
Costa, M. and Michel, F. 1997. Rules for RNA recognition of GNRA tetraloops deduced by in vitro selection: Comparison with in vivo evolution. EMBO J. 16:3289-3302.

Fahy, E., Kwoh, D.Y., and Gingeras, T.R. 1991. Self-sustained sequence replication (3SR): An isothermal transcription-based amplification system alternative to PCR. PCR Methods Appl. 1:25-33.

Frank, D.N. and Pace, N.R. 1997. In vitro selection for altered divalent metal specificity in the RNase P RNA. Proc. Natl. Acad. Sci. U.S.A. 94:14355-14360.

Frank, D.N., Ellington, A.E., and Pace, N.R. 1996. In vitro selection of RNase P RNA reveals optimized catalytic activity in a highly conserved structural domain. RNA 2:1179-1188.

Gilbert, W. 1986. The RNA world. Nature 319:618.

Gold, L., Polisky, B., Uhlenbeck, O., and Yarus, M. 1995. Diversity of oligonucleotide functions. Annu. Rev. Biochem. 64:736-797.

Green, R., Ellington, A.D., and Szostak, J.W. 1990. In vitro genetic analysis of the Tetrahymena selfsplicing intron. Nature 347:406-408.

Guatelli, J.C., Whitfield, K.M., Kwoh, D.Y., Barringer, K.J., Richman, D.D., and Gingeras, T. R. 1990. Isothermal, in vitro amplification of nucleic acids by a multienzyme reaction modeled after retroviral replication. Proc. Natl. Acad. Sci. U.S.A. 87:1874-1878.

Guerrier-Takada, C., Gardiner, K., Marsh, T., Pace, N., and Altman, S. 1983. The RNA moiety of ribonuclease $\mathrm{P}$ is the catalytic subunit of the enzyme. Cell 35:849-857.

Herschlag, D. and Cech, T.R. 1990. DNA-cleavage catalysed by the ribozyme from Tetrahymena. Nature 344:405-409.

Jaeger, L. 1997. The new world of ribozymes. Curr. Opin. Struct. Biol. 7:324-335.

Joyce, G.F. and Inouye, T. 1989. A novel technique for the rapid preparation of mutant RNAs. $\mathrm{Nu}$ cleic Acids Res. 17:711-722

Kim, S.H., Quigley, G.J., Suddath, F.L., McPherson, A., Sneden, D., Kim, J.J., Weinzierl, J., and Rich, A. 1973. Three-dimensional structure of yeast phenylalanine transfer RNA: Folding of the polynucleotide chain. Science 179:285-288.

Kruger, K., Grabowski, P.J., Zaug, A.J., Sands, J., Gottschling, D.E., and Cech, T.R. 1982. Selfsplicing RNA: Autoexcision and autocyclization of the ribosomal RNA intervening sequence of Tetrahymena. Cell 31:147-157.

Lehman, N. and Joyce, G.F. 1993. Evolution in vitro of an RNA enzyme with altered metal ion dependence. Nature 361:182-185.

Liu, F. and Altman, S. 1994. Differential evolution of substrates for an RNA enzyme in the presence and absence of its protein cofactor. Cell 77:1093-1100.

Lorsch, J.R. and Szostak, J.W. 1994. In vitro evolution of new ribozymes with polynucleotide kinase activity. Nature 371:31-36.
Milligan, J.F. and Uhlenbeck, O.C. 1989. Synthesis of small RNAs using T7 RNA polymerase. Methods Enzymol. 180:51-62.

Osborne, S.E. and Ellington, A.D. 1997. Nucleic acid selection and the challenge of combinatorial chemistry. Chem. Rev. 97:349-370.

Pan, T. 1995. Novel RNA substrates for the ribozyme from Bacillus subtilis ribonuclease $\mathrm{P}$ identified by in vitro selection. Biochemistry 34:8458-8464

Rashtchian, A. 1994. Amplification of RNA. PCR Meth. Appl. S83-S91.

Robertson, D.L. and Joyce, G.F. 1990. Selection in vitro of an RNA enzyme that specifically cleaves single-stranded DNA. Nature 344:467-468.

Robertus, J.D., Ladner, J.E., Finch, J.T., Rhodes, D., Brown, R.S., Clark, B.F., and Klug, A. 1974. Structure of yeast phenylalanine tRNA at $3 \AA$ resolution. Nature 250:546-551.

Sambrook, J., Fritsch, E.F. and Maniatis, T. (eds.) 1989. Molecular Cloning, 2nd ed. Cold Spring Harbor Laboratory Press, Cold Spring Harbor, N.Y.

Stemmer, W.P.C 1994. Rapid evolution of a protein in vitro by DNA shuffling. Nature 370:389-391.

Symons, R.H. 1992. Small catalytic RNAs. Annu. Rev. Biochem. 61:641-671.

Tsang, J. and Joyce, G.F. 1996. Specialization of the DNA-cleaving activity of a group I ribozyme through in vitro evolution. J. Mol. Biol. 262:31-42.

Vartanian, J.-P., Henry, M., and Wain-Hobson, S. 1996. Hypermutagenic PCR involving all four transitions and a sizeable proportion of transversions. Nucleic Acids Res. 14:2627-2631.

White, H.B. III 1976. Coenzymes as fossils of an earlier metabolic state. J. Mol. Evol. 7:101-104.

Williams, K.P., Imahori, H., Fujimoto, D.N., and Inoue, T. 1994. Selection of novel forms of a functional domain within the Tetrahymena ribozyme. Nucleic Acids Res. 22:2003-2009.

Wincott, F., DiRenzo, A., Shaffer, C., Grimm, S., Tracz, D., Workman, C., Sweedler, D., Gonzalez, C., Scaringe, S., and Usman, N. 1995. Synthesis, deprotection, analysis and purification of RNA and ribozymes. Nucleic Acids Res. 23:26772684.

Wright, M.C. and Joyce, G.F. 1997. Continuous in vitro evolution of catalytic function. Science 267:614-617.

Yuan, Y. and Altman, S. 1994. Selection of guide sequences that direct efficient cleavage of mRNA by human ribonuclease P. Science 263:1269-1273.

Zhao, H., Giver, L., Shao, Z., Affholter, J.A., and Arnold, F. H. 1998. Molecular evolution by staggered extension process (StEP) in vitro recombination. Nature Biotechnol. 16:258-261.

Contributed by Ronald R. Breaker

Yale University

New Haven, Connecticut
Combinatorial Methods in Nucleic Acid Chemistry 